\title{
Distribution of Eurasian minnows (Phoxinus: Cypriniformes) in the Western Balkans
}

\author{
Matej Vucić ${ }^{1}$, Dušan Jelić ${ }^{1}$, Petar Žutinić ${ }^{2}$, Frédéric Grandjean ${ }^{3}$ and Mišel Jelić ${ }^{2, *}$ \\ ${ }^{1}$ Croatian Institute for Biodiversity, Croatian Biological Research Society, Lipovac I. 7, HR-10000 Zagreb, Croatia \\ ${ }^{2}$ University of Zagreb, Faculty of Science, Department of Biology, Rooseveltov trg 6, HR-10000 Zagreb, Croatia \\ ${ }^{3}$ Université de Poitiers, UMR CNRS 7267, Laboratoire "Ecologie et Biologie des Interactions", équipe "Ecologie, Evolution, Symbiose", \\ 6 rue Michel Brunet, 86073 Poitiers, France
}

\begin{abstract}
The Eurasian minnows of the genus Phoxinus are small cyprinid species, widely distributed across Europe and Asia. Currently, there are at least 15 species in Phoxinus, with preliminary data suggesting more to be described. Despite the discernible increase in research integrating molecular phylogenetic approaches with traditional taxonomy and systematics, inter- and intraspecific relationships in the genus Phoxinus are still poorly known. The aims of this research were to: (i) compile data on the distribution of Phoxinus species in Croatia and Bosnia and Herzegovina from the sampling conducted by authors from 2006 to 2016 and from literature sources, and (ii) provide a detailed insight on distribution ranges of genetic clades and species of Phoxinus in the western Balkans. Additional 118 localities in Croatia and 8 locations in Bosnia and Herzegovina were added to already known 160 localities from the literature data. Molecular analyses of mitochondrial DNA indicate: (i) the presence of Phoxinus marsilii in Croatia (Drava drainage, the Papuk Mountain), around $260 \mathrm{~km}$ south of its known distribution range in Hungary, and (ii) an exceptional genetic variability of P. lumaireul in the Western Balkans.
\end{abstract}

Keywords: Phoxinus marsilii / Phoxinus lumaireul / cryptic species / distribution range / cytochrome b

Résumé - Répartition des vairons d'Eurasie (Phoxinus: Cypriniformes) dans les Balkans occidentaux. Les vairons eurasiens du genre Phoxinus sont de petites espèces de cyprinidés, largement répandues en Europe et en Asie. À l'heure actuelle, il y a au moins 15 espèces de Phoxinus, et des données préliminaires suggèrent d'autres espèces à décrire. Malgré l'augmentation perceptible de la recherche intégrant les approches phylogénétiques moléculaires avec la taxonomie et la systématique traditionnelles, les relations interspécifiques et intraspécifiques dans le genre Phoxinus sont encore mal connues. Les objectifs de cette recherche étaient les suivants: i) compiler des données sur la répartition des espèces de Phoxinus en Croatie et en Bosnie-Herzégovine à partir de l'échantillonnage effectué par les auteurs de 2006 à 2016 et de sources bibliographiques, et ii) fournir un aperçu détaillé des aires de répartition des clades génétiques et des espèces de Phoxinus dans les Balkans occidentaux. 118 localités supplémentaires en Croatie et 8 localités en Bosnie-Herzégovine ont été ajoutées aux 160 localités déjà connues d'après les données de la littérature. Les analyses moléculaires de l'ADN mitochondrial indiquent: i) la présence de Phoxinus marsilii en Croatie (bassin de la Drava, montagne Papuk), à environ $260 \mathrm{~km}$ au sud de son aire de répartition connue en Hongrie, et ii) une variabilité génétique exceptionnelle de $P$. lumaireul dans les Balkans occidentaux.

Mots-clés : Phoxinus marsilii / Phoxinus lumaireul / espèces cryptiques / aire de répartition / cytochrome b

\footnotetext{
*Corresponding author: misel.jelic@biol.pmf.hr
} 


\section{Introduction}

The genus Phoxinus has a wide distribution range throughout the Palaearctic region (basins of Atlantic, North and Baltic Seas, the Arctic and the northern Pacific Ocean), from the Ebro drainage in Spain eastward to Anadyr and Amur drainages in Russia and China. Since the beginning of the 20th century, minnows have expanded outside their native distribution range, especially in the mountain areas of Scandinavia where they were used as live bait (Museth et al., 2007) and Pyrenees as a by-product of trout stocking (Miró and Ventura, 2015). Presently, the Eurasian minnows of the genus Phoxinus include at least 15 species (Eschmeyer et al., 2017) adapted to cold and well-oxygenated waters of fast-flowing mountain streams, large lowland rivers and lakes (Kottelat and Freyhof, 2007).

Besides type species Phoxinus phoxinus (Linnaeus, 1758), following species of Phoxinus in Europe were described based on morphological characters: Phoxinus lumaireul (Schinz, 1840), Phoxinus colchicus Berg, 1910, Phoxinus strandjae Drensky, 1926, Phoxinus biggeri Kottelat, 2007, Phoxinus septimaniae Kottelat, 2007, and Phoxinus strymonicus Kottelat, 2007 (Kottelat and Freyhof, 2007). According to Kottelat and Freyhof (2007), two Phoxinus species inhabit the Western Balkans, with Croatia and Bosnia and Herzegovina as its parts: (i) P. phoxinus in the Danube drainage, and (ii) $P$. lumaireul in the Adriatic basin. However, genetic evidence from Palandačić et al. $(2015,2017)$ suggested several new species in the Western Balkans. Also, morphological examination of specimens collected in Italy, Croatia, Bosnia and Herzegovina, Montenegro and Albania led to description of Phoxinus ketmaieri Bianco and De Bonis, 2015, Phoxinus likai Bianco and De Bonis, 2015, Phoxinus apollonicus Bianco and De Bonis, 2015, and Phoxinus karsticus Bianco and De Bonis, 2015.

Although Croatian and Bosnian karstic area is known for its high diversity and endemicity of freshwater ichthyofauna (Jelić et al., 2016), three of four species described by Bianco and De Bonis (2015) cannot be validated using molecular species delimitation analyses (Palandačić et al., 2017). Two of them ( $P$. ketmaieri and $P$. likai) were synonymised with $P$. lumaireul, whereas $P$. apollonicus was synonymised with $P$. karsticus (Palandačić et al., 2017). Also, the 8\% genetic divergence between $P$. lumaireul and $P$. phoxinus on cytochrome c oxidase subunit 1 (COI) supports revalidation of $P$. lumaireul by Kottelat (2007) and rejects synonymization of $P$. lumaireul and $P$. phoxinus made by Bianco and De Bonis (2015).

The morphological examination of Eurasian minnows is a challenging task due to phenotypic plasticity of the group (Ramler et al., 2017), the lack of holotype specimens and the existence of cryptic species. Cryptic species within the genus Phoxinus are morphologically indistinguishable and molecular taxonomy studies could provide efficient means for uncovering cryptic species diversity (Palandačić et al., 2017). Within the European Phoxinus, morphological characters which are traditionally used in taxonomy, cannot provide clear phylogenetic information, and sometimes disagree in validity of some Phoxinus species (e.g. P. lumaireul) (Palandačić et al., 2017). Morphology of Phoxinus is very affected by habitat type and intraspecies differences in body shape that can be large as those observed on interspecific level. Intraspecific morphological differences can be linked to different swimming modes and foraging in distinct habitats such as lakes and streams (Ramler et al., 2017; Collin and Fumagalli, 2011).

The lack of holotype specimen of type species $P$. phoxinus was resolved by creating its neotype from the Agger River (Rhine drainage) in Germany (Kottelat, 2007). However, recent barcoding of fishes in rivers Rhine and Weser indicated the existence of two divergent Phoxinus lineages (Knebelsberger et al., 2014). Moreover, the mixing zone of four lineages was detected in the same area in Germany (Palandačić et al., 2017). The designations of many Phoxinus species as synonyms of $P$. phoxinus (e.g. the list of synonyms provided by Kottelat, 2007) become questionable because analysed material originated from hybrid zone. However, there is a good example of research (Palandačić et al., 2017) which combines analyses on molecular data and morphology to resolve taxonomic problems in Phoxinus; the DNA analyses of museum material enabled re-establishing two species: Phoxinus csikii Hankó, 1922 from the Bijelo polje in Montenegro, and Phoxinus marsilii Heckel, 1836 from the Danube River near Vienna.

The high level of diversity and complex phylogeography of species which co-exist with the Eurasian minnows in the Balkans (Klobučar et al., 2013; Buj et al., 2008; Mamos et al., 2016; Vitecek et al., 2017; Simonović et al., 2017), together with dynamic geology (Karamata, 2006), suggest that the "Balkan minnow" represents heterogeneous complex (Palandačić et al., 2015, 2017). In line with this, the aims of this research were to: (i) collect all available literature data on distribution of Phoxinus in Croatia and Bosnia and Herzegovina, and conduct targeted sampling for new and missing data, (ii) compare the compiled data in the light of recent molecular research Palandačić et al. $(2015,2017)$ and (iii) provide an insights of the present situation within the genus Phoxinus in Western Balkans, using new sequences of mitochondrial DNA obtained in the present study.

\section{Materials and methods}

\subsection{Data collection}

The present study comprises data collected by the authors from 2006 to 2016 (Tab. S1), and all available literature data on species of Phoxinus in Croatia and Bosnia and Herzegovina (Tabs. S1 and S2).

The sampling of Phoxinus was conducted by hand net sampling and electrofishing method. Electrofishing was performed with Hans Grassl EL63 IIGI (300/600 V, $5000 \mathrm{~W}$ ) and SAMUS $725 \mathrm{MP}$ (max. $1000 \mathrm{~V}, 650 \mathrm{~W}$; Samus Special Electronics, Poland). Sampling was performed for $20 \mathrm{~min}$ on a $100 \mathrm{~m}$ transect upstream from the previously chosen starting point. All types of habitats were covered on every site. The collected specimens were determined as members of the genus Phoxinus using morphological characters described in Kottelat and Freyhof (2007). Further identification of species was based on sequences of mitochondrial gene for cytochrome b (cyt-b).

Literature data were collected from the following references: Heckel and Knerr (1858), Seeley (1886), 
Steindachner (1866), Glowacki (1885, 1896), Brusina 1892, Hirc (1896), Plančić (1956), Sabioncello (1967), Pažur (1969), Vuković and Ivanović (1971), Sofradžija (1981, 2009), Leiner (1985, 1998), Tvrtković (1985), Bianco (1986), Lelek (1987), Mrakovčić and Mišetić (1988), Meštrov et al. (1989a, b), Fašaić et al. (1990), Delić (1993), Mrakovčić et al. (1996, 2007, 2010, 2014), Trgovčić (2003), Kottelat (2007), Sallai and Mrakovčić (2007), Primc Habdija et al. (2008), Habdija et al. (2008), Delić et al. (2009), Buj (2010), Jalžić et al. (2010), Miočić-Stošić et al. (2012), Valić et al. (2013), Palandačić et al. (2015) and Simonović et al. (2015) (Tabs. S1 and S2).

\subsection{Molecular analyses}

Total genomic DNA was isolated from pectoral fin tissue using the Qiagen DNeasy Blood and Tissue Kit (Qiagen, Germany) and following the manufacturer protocol. DNA was stored on $-20{ }^{\circ} \mathrm{C}$ until the polymerase chain reaction (PCR) was conducted. Fragments of the cyt-b gene were amplified using primer pair GluF and ThrR (Machordom and Doadrio, 2001), following cycling conditions as described in Perea et al. (2010). PCR reactions were performed using HotStarTaq Master Mix Kit (Qiagen), in a total volume of $50 \mu \mathrm{L}$ comprised of $2.5 \mathrm{U}$ HotStarTaq DNA Polymerase, $1.5 \mathrm{mM} \mathrm{MgCl}_{2}, 200 \mu \mathrm{M}$ each dNTP, $0.2 \mu \mathrm{M}$ of each primer and $20 \mathrm{ng}$ of DNA template. Purification and sequencing of the PCR products were prepared by Macrogen Inc. (Seoul, South Korea) using the same primers used for gene amplification. Purified PCR products were sequenced on ABI 3730XL DNA Analyzer (Applied Biosystems, Foster City, USA). Sequence trace files were analysed using SEQUENCHER (version 5.3; Gene Codes Corp., Ann Arbor, USA).

Phylogenetic analyses were conducted using the cyt-b sequences obtained in the present study and the available sequences of Phoxinus (1091 BP) from Croatia, Bosnia and Herzegovina and neighbouring countries which were downloaded from the GenBank (Tab. S1; Palandačić et al., 2015). New sequences were deposited in the GenBank under accession numbers shown in Table S1. Phylogenetic relationships were inferred using two methods (Maximum Likelihood - ML and Bayesian Inference - BI). The Tamura-Nei ( TrN) model (Tamura and Nei, 1993) with a gammadistributed rate variation among sites $(+G)$ was selected as the best-fit evolutionary model using the Bayesian information criterion (BIC) in jModelTest2 (version 2.1.6; Darriba et al., 2012). The ML was run in RAxML-HPC2 Workflow on XSEDE (version 8.2.8; Stamatakis, 2014) on the Cipres Science Gateway (version 3.1; http://www.phylo.org; Miller et al., 2010) with optimised parameters. ML analysis was conducted with 200 search replicates to find the ML tree and 1000 nonparametric bootstrap replicates, using MrBayes 3.2 (Ronquist et al., 2012) on the Cipres Science Gateway. Two independent runs with four MCMC chains were run for 50 million generations and sampled every 5000 generations. Temperature parameter was set to 0.2 and the first 12.5 million generations were discarded as burn-in. The effective sample sizes of parameters were screened using TRACER 1.5 (Drummond and Rambaut, 2007) whereas the convergence of runs was checked using AWTY
(Nylander et al., 2008). Nodes in the phylogenetic tree which have bootstrap values $P \geq 70$ in $\mathrm{ML}$, and posterior probabilities (pp) values $\geq 0.95$ in BI were considered supported.

In cases of uncertain determinations of genetic clades in phylogram, Nucleotide Basic Local Alignment Search Tool (Nucleotide BLAST; http://blast.ncbi.nlm.nih.gov/Blast.cgi) was used to obtain their systematic position.

The Median-Joining (MJ) haplotype networks were used to infer the intraspecific relations (Bandelt et al., 1999). The MJ networks were constructed using PopART (Population Analysis with Reticulate Trees) v1.7 (Leigh and Bryant, 2015).

The number of base substitutions per site from estimation of net average between sequence groups in $P$. lumaireul was calculated using the $\operatorname{TrN}+\mathrm{G}$ model in MEGA6 (Tamura et al., 2013). Standard error estimates were obtained by a bootstrap procedure (1000 replicates).

All of the data were analysed with ESRI ArcInfo GIS v10.2.2 software (ESRI, 2014) to plot distribution ranges of Phoxinus species in Croatia and Bosnia and Herzegovina.

\section{Results}

\subsection{General overview on the distribution of Phoxinus in Croatia and Bosnia and Herzegovina}

In this paper, we present the distribution of Phoxinus in Croatia and Bosnia and Herzegovina, in rivers which are part of the Black Sea basin (rivers Sava, Drava and Danube) and Adriatic basin. Altogether 126 new localities were sampled, with 118 in Croatia and 8 in Bosnia and Herzegovina (Fig. 1, Tab. S1). From 160 localities cited in the literature, 133 are from Croatia and 27 are from Bosnia and Herzegovina (Fig. 1, Tabs. S1 and S2). From a total of 286 localities, 73 sites were positioned in the Adriatic basin and 213 sites were in the Black Sea basin (Fig. 1).

The Eurasian minnows were recorded in small streams on the slopes of continental mountain systems in Croatia with peaks up to $953 \mathrm{~m}$ above sea level (Papuk, Bilogora, Krndija, etc.; Drava and Sava drainages). Minnows were also recorded in the fast flowing, well-oxygenated lowland streams, tributaries of the largest Croatian rivers Drava and Sava (near Varaždin in northern Croatia and the Banovina region in central Croatia, respectively). Specimens morphologically determined as Phoxinus were also found in the upper courses of Istrian rivers in the Adriatic basin (Mirna, Raša), as well in the rivers Zrmanja, Krka and Neretva and their tributaries (Dalmatia region, southern Croatia, Adriatic basin). Analysis of literature and sampling data showed that the Eurasian minnows are distributed in the upper and middle courses of large rivers in Bosnia and Herzegovina, such as Una, Drina, Bosna and Vrbas, as well in their smaller tributaries (Sava drainage). Species of Phoxinus were absent from the lower courses of Sava, Drava and Danube. There is only one literature record of Phoxinus sp. in the lower course of Sava River, the largest tributary of the Danube River in Croatia and Bosnia and Herzegovina (Brusina, 1892). Specimens of Phoxinus were not recorded in lower courses of rivers Mirna and Raša (Adriatic basin, Istra region, Croatia), the Cetina River in the middle part of Dalmatia in Croatia (Adriatic basin), as well as in several large karst fields (poljes) in the 


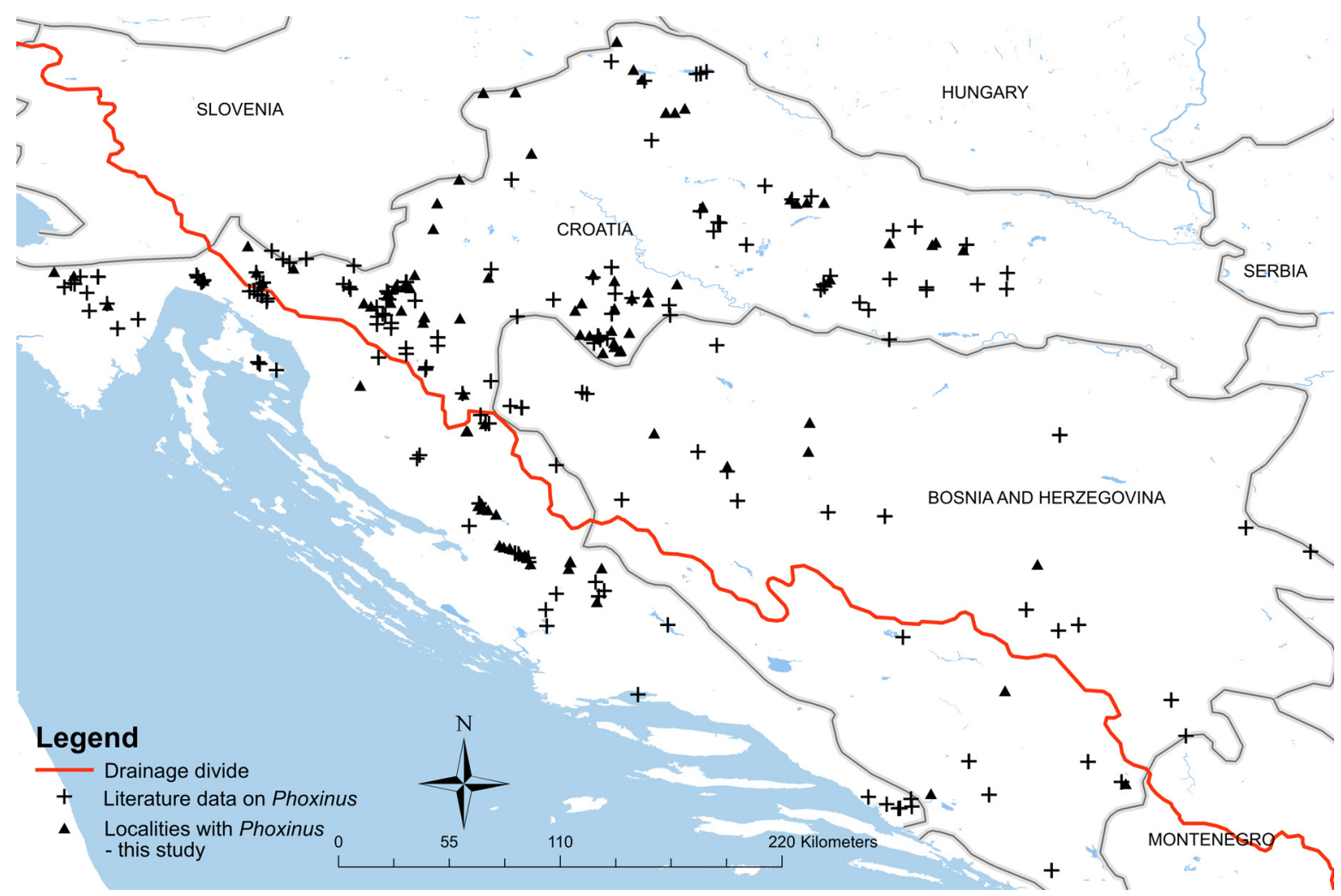

Fig. 1. Distribution of Phoxinus (Cypriniformes: Cyprinidae) in Croatia and Bosnia and Herzegovina. New localities from the sampling conducted by authors of the present study are presented by triangles, whereas localities reported in the literature are marked by crosses. The drainage divide between the Black Sea basin and the Adriatic basin is indicated by the thick red line.

Dinaric Alps, such as Duvanjsko, Livanjsko and Grahoračko polje (Adriatic basin, Bosnia and Herzegovina). The species of Phoxinus were also not found in other small and isolated karst poljes, such as Mostarsko blato, Nevesinjsko polje, Dabarsko polje, Fatničko polje (Neretva drainage, Adriatic basin, Bosnia and Herzegovina), Drniško polje (Čikola River system, Krka drainage, Adriatic basin, Croatia), Stajničko polje, Drežničko polje, and Crnac polje (Dobra River system, Sava drainage, Croatia).

\subsection{Distribution of genetic clades/species of Phoxinus in Croatia and Bosnia and Herzegovina}

Phylogenetic reconstruction (Fig. 2) combined with the BLAST search resulted in detection of $P$. marsilii, $P$. lumaireul (clades 1a, 1b, 1c and 1d), P. karsticus, Clade 2: Phoxinus sp. 1 sensu Palandačić et al. (2017), and Clade 6: Phoxinus sp. 4 sensu Palandačić et al. (2017).

P. marsilii was recorded in Croatia for the first time (Drava drainage). In total eight new haplotypes of $P$. marsilii were detected in three populations on the northern slopes of Papuk Mountain (Fig. 3, Tab. S1). MJ networks using all available sequences of $P$. marsilii (Fig. 4) indicated that the examined specimens from Croatia belong to Clade 9a sensu Palandačić et al. (2017). The central haplotype in the part of MJ network with Croatian haplotypes (H187, Fig. 4a) differs by one mutational step from haplotype H194 which is distributed in Austria and Poland.

In the present study, 83 haplotypes of $P$. lumaireul are recorded, 72 of which are new (Fig. 2, Tab. S1). Intraspecific relations in $P$. lumaireul were additionally analysed in the MJ haplotype network (Fig. 5) using 185 available haplotypes (Tab. S1). P. lumaireul are represented by clades $1 \mathrm{a}, 1 \mathrm{~b}, 1 \mathrm{c}$ and 1d, all of which were recorded in Croatia, whereas only Clade $1 \mathrm{~b}$ was found in Bosnia and Herzegovina. Two clades of $P$. lumaireul were recorded for the first time in Croatia: (i) Clade 1c in the westernmost river systems of Sava drainage (Sutla River, Bregana River, and Jamno Stream in the Medvednica Mountain), and (ii) Clade $1 \mathrm{~d}$ in the westernmost river systems of Drava drainage in Croatia (Zbelava Stream in the Plitvica River system, and a channel near Varaždin; Figs. 3 and 5). The highest number of haplotypes (75; Fig. 5) was detected in Clade $1 \mathrm{~b}$.

Additionally, we introduced nine lineages within $P$. lumaireul clades $1 \mathrm{a}, 1 \mathrm{~b}, 1 \mathrm{c}$ and $1 \mathrm{~d}$ to describe fine-scale geographic distribution of genetic groups in $P$. lumaireul, which differ by at least 8 mutational steps in MJ network (Clade 1a Lineage HR, Clade 1a Lineage SI/HR, Clade 1a Lineage IT1, Clade 1a Lineage IT2, Clade 1a Lineage IT3, Clade 1b Lineage HR/SI/BA, Clade 1b Lineage HR/BA, Clade 1c Lineage SI/HR, and Clade 1c Lineage SI; Fig. 5). Moreover, the $\operatorname{TrN}+\mathrm{G}$ genetic distances among genetic groups in $P$. lumaireul were calculated (Tab. 1), showing a minimum of 
M. Vucić et al.: Knowl. Manag. Aquat. Ecosyst. 2018, 419, 11

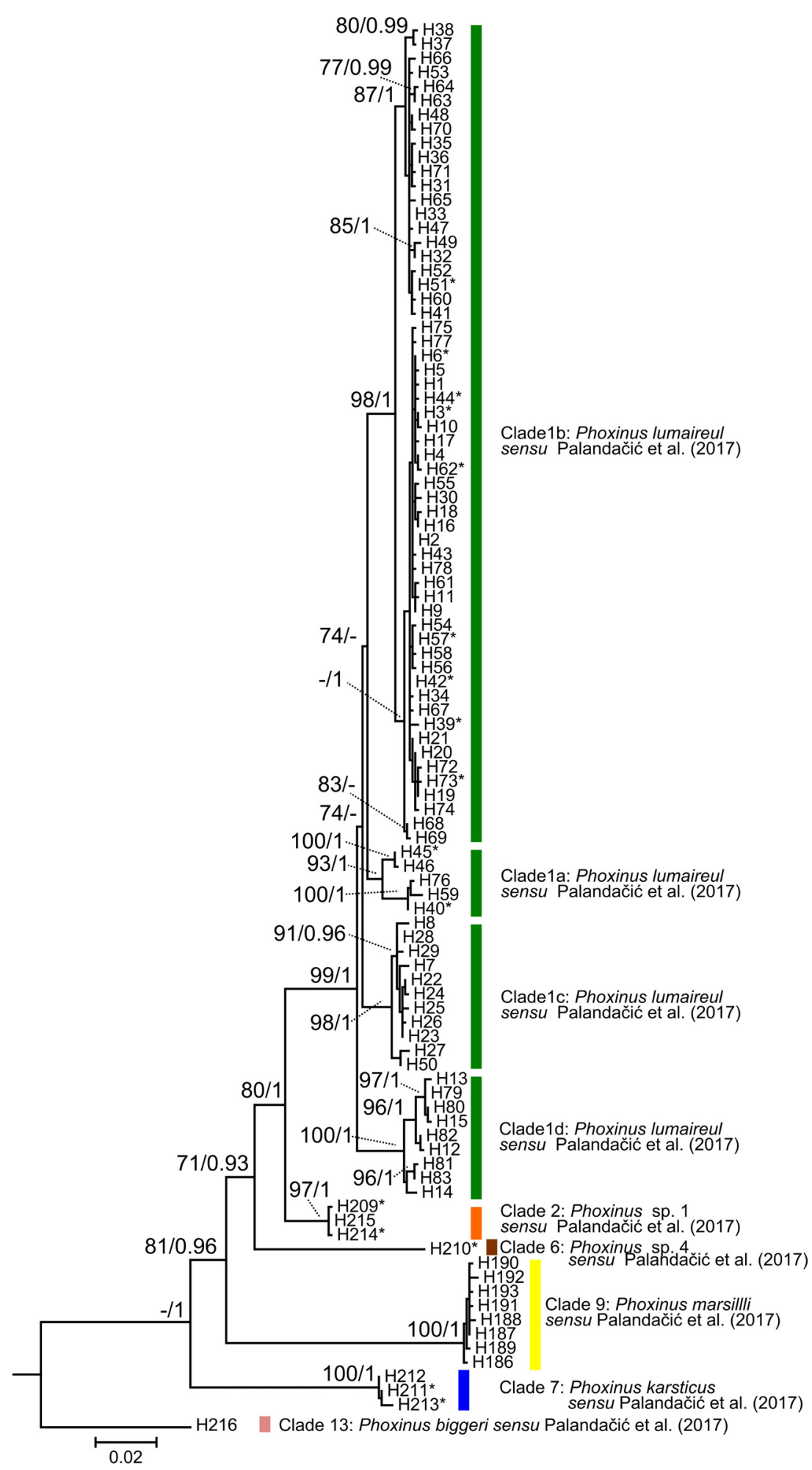

Fig. 2. Phylogram inferred by Maximum Likelihood (ML) analysis using cytochrome b (cyt-b) sequences obtained in the present study. Node supports are given as bootstrap values $(P)$ in ML analysis (showing values $\geq 70$ ) and posterior probabilities (pp) in Bayesian Inference (BI; showing values $\geq 0.9$ ). Phoxinus biggeri from France was used as outgroup. 


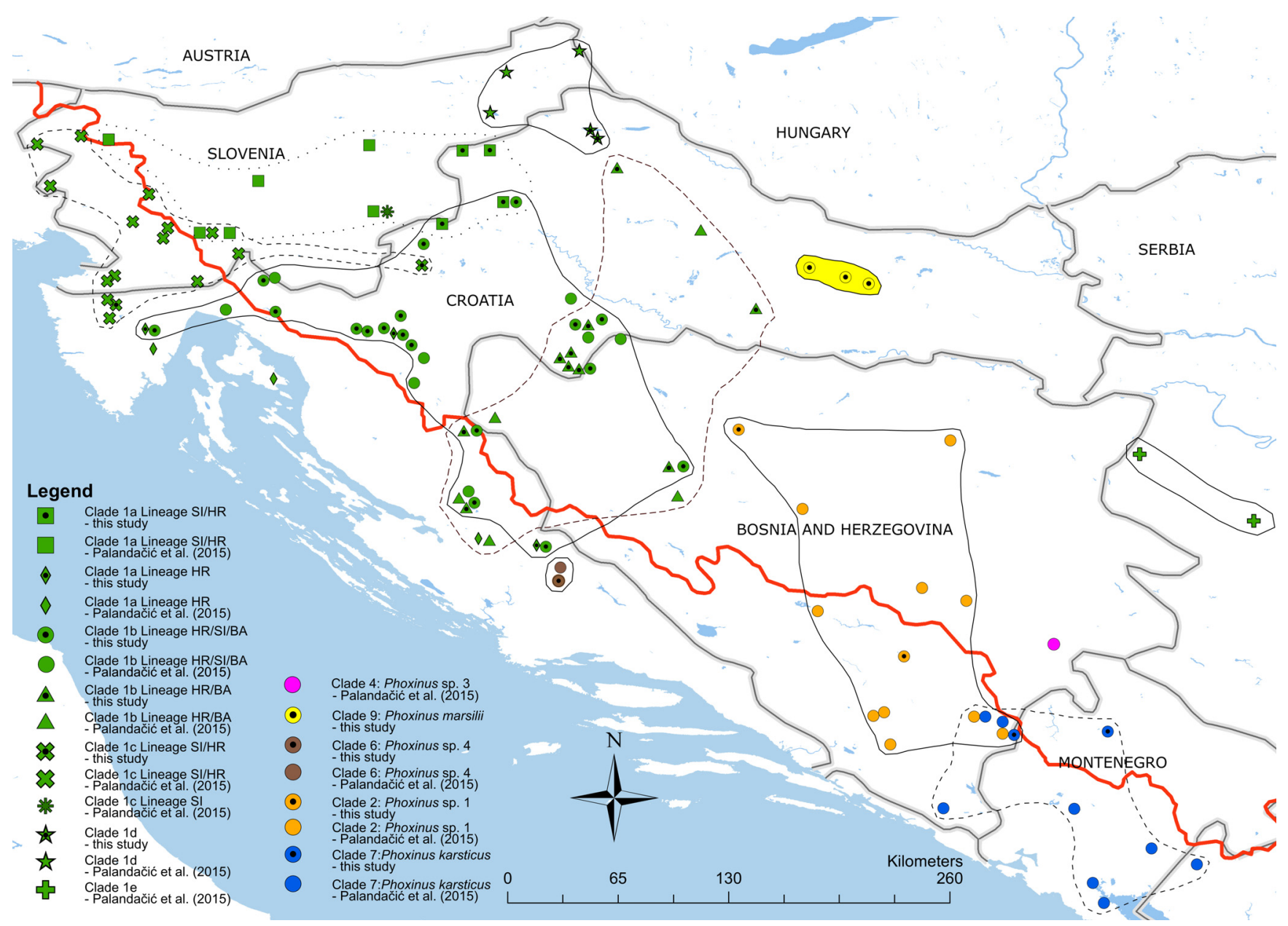

Fig. 3. Distribution ranges of genetic clades, lineages and species. Names of clades and species follow Palandačić et al. (2017). The genus Phoxinus in the Western Balkans is presented with data on localities from the sampling conducted in present study compiled with localities from Palandačić et al. (2015). The drainage divide between the Black Sea basin and the Adriatic basin is indicated by the thick red line.

$0.6 \%$ [standard error (S.E.) $0.2 \%$ ] base substitutions per site from estimation of net average between sequence groups which correspond to Clade 1a Lineage SI/HR and Clade 1a IT3, and a maximum of $4.1 \%$ (S.E. $0.7 \%$ ) between Clade 1a Lineage IT2 and Clade 1f sensu Palandačić et al. (2017). Geographic distribution of clades and lineages of $P$. lumaireul is presented in Figure 3.

\section{Discussion}

\subsection{Collection of literature and sampling data of the genus Phoxinus in Croatia and Bosnia and Herzegovina - general remarks on the distribution range}

Literature and sampling data indicate that species of Phoxinus are common and widely distributed in Croatia and Bosnia and Herzegovina (Fig. 1). Despite its wide distribution range in both countries, the European minnow can be found mostly in cold and well-oxygenated brooks and streams of uplands of Danube drainage and Adriatic basin, a common type of Phoxinus habitat as described in Kottelat and Freyhof(2007). Species of Phoxinus seem to be absent from the lower courses of large lowland rivers of the Black Sea basin (rivers Sava, Drava and Danube), lower courses of rivers in Istria and Ravni Kotari (Adriatic basin) and the Cetina drainage, as the only large drainage in the Adriatic basin where Phoxinus was not detected. The largest lowland rivers in Croatia and Bosnia and Herzegovina (Sava, Drava and Danube) presumably do not contain favourable slope with fast flowing water and enough turbidity and oxygenation to support populations of Phoxinus. Species of Phoxinus were recorded in the upper courses of large Bosnian rivers (Una, Drina, Bosna and Vrbas; Sava drainage) as well as in their small tributaries. However, they were not recorded in their lower courses (Fig. 1; Simonović et al., 2015).

\subsection{Updates of molecular data for the genus Phoxinus in Western Balkans}

\subsubsection{The first record of Phoxinus marsilii in Croatia}

Detection of $P$. marsilii in the Drava drainage in Croatia supports the placement of this drainage in the Upper Danube 


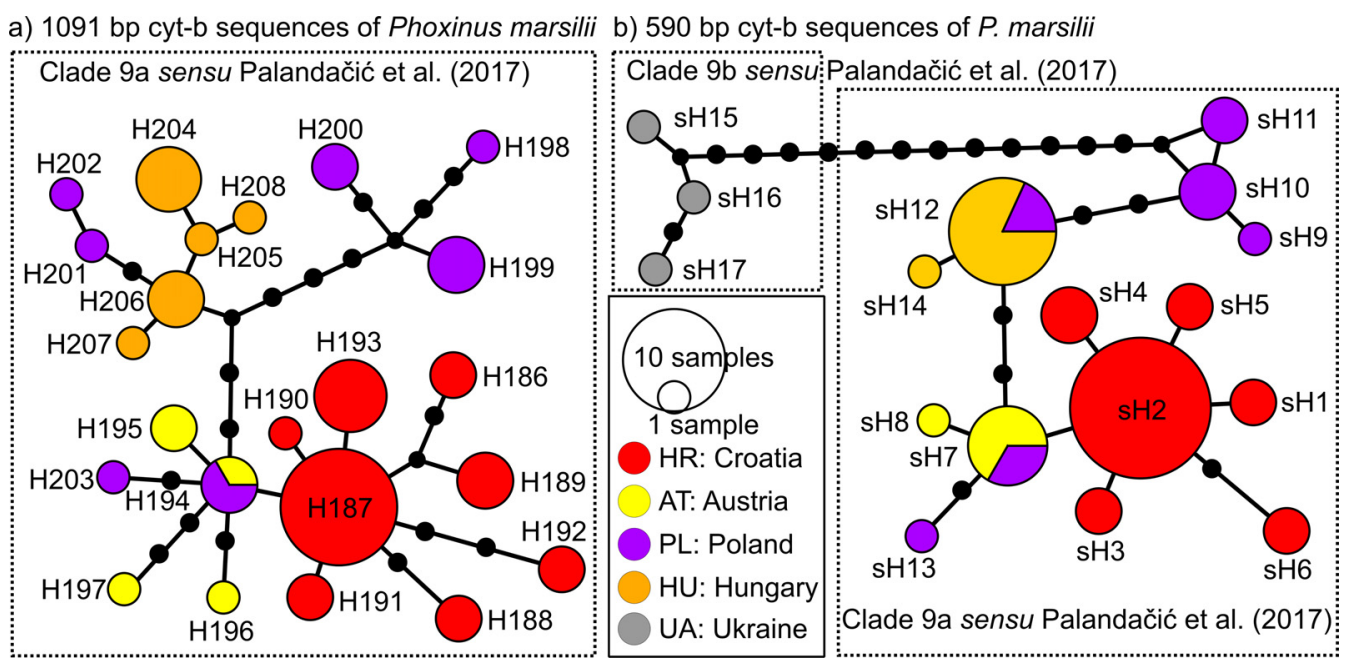

Fig. 4. Median-Joining (MJ) haplotype networks of Phoxinus marsilii. Haplotypes were shown with codes ranging: (a) from H186 to H208 in 1091 BP cyt-b sequences, and (b) from sH1 to sH14 in 590 BP cyt-b sequences. Mutational steps and median vectors were represented by black circles.

freshwater ecoregion sensu Abell et al. (2008), which was also confirmed by the presence of Clade 1d of P. lumaireul in Drava drainage in Croatia and Slovenia. The distribution range of $P$. marsilii in Croatia overlaps with the distribution range of the Clade VI of Sabanejewia balcanica (Karaman, 1922) detected in the river systems on the northern slopes of Papuk Mountain (Buj et al., 2008) and the Mur River in Austria (Perdices et al., 2003).

The only one mutational step between a haplotype obtained from Croatian specimens of P. marsilii (H187, Fig. 4) and a haplotype detected in specimens of $P$. marsilii from Austria and Poland (H194, Fig. 4) indicate that the dispersal of $P$. marsilii over a large area in Central Europe can be connected either with the last Pleistocene glacial-interglacial periods or human-mediated translocation.

\subsubsection{New insights into the genetic variability of Phoxinus lumaireul}

Results from molecular data confirmed that $P$. lumaireul is a dominant species of minnow in Croatia. This species is also reported in the westernmost river systems of Sava drainage in Bosnia and Herzegovina (Fig. 3). A remarkable genetic variability of $P$. lumaireul across the entire known distribution range (Italy, Slovenia, Austria, Croatia, Bosnia and Herzegovina, and Serbia) indicates a complex evolutionary history driven by geological features of karstic freshwater environment (Bosák, 2008; Prelovšek, 2010) and climate oscillations during Pleistocene (Schmitt, 2007). It can be presumed that the distribution of clades and lineages of $P$. lumaireul is connected with the existence of several glacial refugia, point out to the phylogeographic scenario of "refugia within refugia" (Gómez and Lunt, 2006). Moreover, evolutionary histories of many freshwater taxa with the overlapping distribution ranges with $P$. lumaireul can be explained by this scenario e.g. the brown trout (Simonović et al., 2017), caddisflies (Previšić et al., 2009), Asellus aquaticus (Verovnik et al., 2005), the stone crayfish (Klobučar et al., 2013) and the white-clawed crayfish (Jelić et al., 2016).

High dispersal potential of $P$. lumaireul enabled secondary contacts and mixture of clades and lineages (Figs. 3 and 5).
Moreover, P. lumaireul crossed through the drainage divide between the Black Sea and Adriatic basins in Slovenia and Croatia (Fig. 3), making it hard to interpret whether by natural dispersal or human-mediated translocation. Particularly, the central haplotype H45 in Clade 1a Lineage SI/HR (Fig. 5) was detected in Kupa (Kolpa) River system (Sava drainage, Croatia and Slovenia), several isolated river systems in Slovenia (Sava drainage and Adriatic basin) and Istra peninsula (Adriatic basin, Croatia).

The sympatry of minnows and salmonids (Museth et al., 2007; Kottelat, 2007; Kottelat and Freyhof, 2007) supports the hypothesis of introductions of Phoxinus species throughout the Europe through fish trade and recreational fishing practice. Caution is needed in biogeographic interpretation because human-mediated translocations of Phoxinus species could mask their natural distribution ranges (Kottelat, 2007). For example, the mixture of clades 1a (H140, H170, and H171) and $1 \mathrm{~b}$ (H51 and H167) of P. lumaireul in the Zrmanja drainage (Figs. 3 and 5; Palandačić et al., 2015) could be a result of water exchange between Razovac Lake (Zrmanja drainage, Dalmatia region, Adriatic basin, Croatia) and Stikada Lake (Ričica and Otuča river system, Lika region, Adriatic basin, Croatia) by the reversible power plant "Velebit" rather than a natural dispersal.

\subsubsection{Remarks on other species in Croatia and Bosnia and Herzegovina}

According to Palandačić et al. $(2015,2017)$, the population from the Krka drainage (Adriatic basin, Croatia) represents a very distinct clade (Clade 6: Phoxinus sp. 4) and could be considered a new species. The examination of Krka specimens confirmed two haplotypes reported in Palandačić et al. (2015) and detected one new haplotype (Fig. 2). Even though the distribution range of this species remained unchanged, extensive research on the size and genetic parameters of the population and its distribution is required.

The Clade 4: Phoxinus sp. 3 described from the Drina River system by Palandačić et al. (2017) was not detected in 




Fig. 5. Median-Joining (MJ) haplotype network of Phoxinus lumaireul. Haplotypes were shown with codes ranging from H1 to H185. Mutational steps and median vectors were represented by black circles.

Table 1. The number of base substitutions per site from estimation of net average between sequence groups using the Tamura-Nei model with a gamma-distributed rate variation among sites (Tamura and Nei, 1993). Values are shown as percentage. Sequence groups correspond to clades and lineages in Phoxinus lumaireul. Standard error estimates are shown above the diagonal.

\begin{tabular}{|c|c|c|c|c|c|c|c|c|c|c|c|c|}
\hline Clades and lineages & 1 & 2 & 3 & 4 & 5 & 6 & 7 & 8 & 9 & 10 & 11 & 12 \\
\hline 1. Clade 1a Lineage HR & - & 0.3 & 0.3 & 0.4 & 0.3 & 0.5 & 0.4 & 0.6 & 0.5 & 0.6 & 0.6 & 0.6 \\
\hline 2. Clade 1a Lineage SI/HR & 1.2 & - & 0.3 & 0.4 & 0.2 & 0.5 & 0.4 & 0.5 & 0.4 & 0.5 & 0.5 & 0.6 \\
\hline 3. Clade 1a Lineage IT1 & 0.9 & 1 & - & 0.4 & 0.3 & 0.5 & 0.5 & 0.6 & 0.5 & 0.6 & 0.5 & 0.6 \\
\hline 4. Clade 1a Lineage IT2 & 1.4 & 1.4 & 1.6 & - & 0.4 & 0.5 & 0.5 & 0.5 & 0.5 & 0.5 & 0.5 & 0.7 \\
\hline 5. Clade 1a Lineage IT3 & 1.1 & 0.6 & 0.9 & 1.3 & - & 0.4 & 0.4 & 0.5 & 0.4 & 0.5 & 0.5 & 0.6 \\
\hline 6. Clade $1 \mathrm{~b}$ Lineage $\mathrm{HR} / \mathrm{BA}$ & 2.5 & 2.2 & 2.4 & 2.5 & 2.1 & - & 0.3 & 0.5 & 0.4 & 0.6 & 0.5 & 0.6 \\
\hline 7. Clade $1 \mathrm{~b}$ Lineage $\mathrm{HR} / \mathrm{SI} / \mathrm{BA}$ & 2.1 & 2 & 2.1 & 2.5 & 1.9 & 0.9 & - & 0.5 & 0.4 & 0.6 & 0.5 & 0.6 \\
\hline 8. Clade 1c Lineage SI & 2.8 & 2.3 & 2.8 & 2.7 & 2.5 & 2.2 & 2.6 & - & 0.4 & 0.6 & 0.5 & 0.6 \\
\hline 9. Clade 1c Lineage SI/HR & 2.3 & 1.8 & 2.3 & 2.3 & 1.9 & 2 & 2 & 1.9 & - & 0.5 & 0.4 & 0.6 \\
\hline 10. Clade 1d & 3.1 & 2.8 & 3.2 & 3.1 & 2.9 & 3.1 & 3.1 & 3.1 & 2.6 & - & 0.4 & 0.4 \\
\hline 11. Clade 1e & 3.5 & 3 & 3.4 & 3.6 & 3.1 & 3.2 & 3 & 3.7 & 2.6 & 2.4 & - & 0.5 \\
\hline 12. Clade $1 \mathrm{f}$ & 3.5 & 3.3 & 3.5 & 4.1 & 3.3 & 3.9 & 3.5 & 3.4 & 3.2 & 2.4 & 2.6 & - \\
\hline
\end{tabular}

sampling in the present study. Changes of distribution ranges (Fig. 3) were reported for Clade 2: Phoxinus sp. 1 sensu Palandačić et al. (2017) and Clade 7: P. karsticus. The Clade 2: Phoxinus sp. 1 was reported in the Vrbas River in Banja Luka (Sava drainage, Bosnia and Herzegovina) what presumably represents the western boundary of its distribution range. The Clade 7: P. karsticus was found in the Tara River (Drina River system in Sava drainage, Montenegro), indicating there could be its hybridization zone with Clade 4: Phoxinus sp. 3 (Fig. 3). Denser sampling is needed to study distribution ranges of four Phoxinus species in Bosnia and Herzegovina. 


\section{Conclusions}

The distribution range of Phoxinus species in Europe considerably expanded throughout the 20th century, especially in the mountain areas of Norway and Pyrenees, due to the usage of minnows as live bait for angling (Museth et al., 2007; Miró and Ventura, 2015). Translocation of minnows without previous species determinations could have led to the introduction of non-native Phoxinus species in drainages occupied by autochthonous species of Phoxinus (Kottelat, 2007). Moreover, introductions of minnows can represent a serious threat to trout fisheries (Museth et al., 2007).

Species descriptions and synonymization in the genus Phoxinus cannot be done solely on morphology and should be supported by molecular analyses. Since the habitatinduced body shape changes (e.g. head length, eye diameter, gape and body width) may blur morphological differences between species or genetic clades (Walker, 1997; Langerhans et al., 2007; Langerhans and Reznick, 2010; Lucek et al., 2016), they should be regarded in all future morphological species delimitations in the genus Phoxinus (Ramler et al., 2017).

Additional taxonomic studies are needed, specifically molecular taxonomy and barcoding projects (Palandačić et al., 2017). However, despite providing a better insight into the systematics of the genus Phoxinus, both molecular taxonomy and barcoding methods have setbacks. Interpretation of results obtained by these methods, especially of COI barcoding as a single-gene approach, should be taken with caution (Palandačić et al., 2017). Besides taking additional samples, possible solutions in resolving the specific and complex phylogenetic relationships in the genus Phoxinus include the use of several unlinked genes (mitochondrial and nuclear), morphology, data on geographic distribution and ecological parameters.

\section{Supplementary Material}

Tables S1 and S2.

The Supplementary Material is available at https://www.kmaejournal.org/10.1051/kmae/2017051/olm.

\section{References}

Abell R, Thieme ML, Revenga C, Bryer M, Kottelat M, Bogutskaya N, Coad B, Mandrak N, Contreras Balderas S, Bussing W, Stiassny MLJ, Skelton P, Allen GR, Unmack P, Naseka A, Ng R, Sindorf N, Robertson J, Armijo E, Higgins JV, Heibel TJ, Wikramanayake E, Olson D, López HL, Reis RE, Lundberg JG, Sabaj Pérez MH, Petry P. 2008. Freshwater ecoregions of the World: a new map of biogeographic units for freshwater biodiversity conservation. Bioscience 58: 403-414.

Bandelt H, Forster P, Röhl A. 1999. Median-joining networks for inferring intraspecific phylogenies. Mol Biol Evol 16: 37-48.

Bianco PG. 1986. The zoogeographic units of Italy and Western Balkans based on cyprinid species ranges (Pisces). Biologia GalloHellenica 12: 291-299.

Bianco PG, De Bonis S. 2015. A taxonomic study on the genus Phoxinus (Acthinopterigy, Cyprinidae) from Italy and western Balkans with description of four new species: P. ketmaieri, P. karsticus, P. apollonicus and P. likai. In Bianco PG, de Filippo G, eds. Researches on Wildlife Conservation, vol. 4, IGF publications. Bosák P. 2008. Karst processes and time. Geologos 14: 19-36.

Brusina S. 1892. Pabirci za hrvatsku ihtiologiju i za ribarstvo. Glasnik HPD 1-6: 221.

Buj I. 2010. Taxonomic status, phylogenetic relationships and morphological characters of spined loaches of the genus Cobitis (Cypriniformes; Actinopterygii) distributed in Dalmatia and Herzegovina, Doctoral thesis, University of Zagreb, Faculty of Science, Division of Biology, Zagreb, $309 \mathrm{p}$.

Buj I, Podnar M, Mrakovčić M, Ćaleta M, Mustafić P, Zanella D, Marčić Z. 2008. Morphological and genetic diversity of Sabanejewia balcanica in Croatia. Folia Zool 57: 100-110.

Collin H, Fumagalli L. 2011. Evidence for morphological and adaptive genetic divergence between lake and stream habitats in European minnows (Phoxinus phoxinus, Cyprinidae). Mol Ecol 20: 4490-4502.

Darriba D, Taboada GL, Doallo R, Posada D. 2012. JModelTest 2: more models, new heuristics and parallel computing. Nat Methods 9: 772 .

Delić A. 1993. Riblja fauna tekućica istočne Bilogore. Ribarstvo 48: $55-60$.

Delić A, Bučar M, Jugović D, Mihoci I, Kučinić M. 2009. New data on the distribution Cobitis elongatoides Bacescu and Maier, 1969 (Cobitidae) in Central Croatia. Nat Croat 18: 255-262.

Drummond AJ, Rambaut A. 2007. BEAST: Bayesian evolutionary analysis by sampling trees. BMC Evol Biol 7: 214.

Eschmeyer WN, Fricke R, van der Laan R. (eds.) 2017. Catalog of fishes: genera, species, references. (http://researcharchive.calaca demy.org/research/ichthyology/catalog/fishcatmain.asp. Electronic version accessed 20.03.2017).

Fašaić K, Mrakovčići M, Mišetić S. 1990. Kemizam vode i ihtioprodukcija Visovačkog jezera NP "Krka". In: Kerovec M, ed. Stanje istraženosti i problemi zaštite ekosistema, Croatian Ecological Society, Zagreb, 365-376.

Glowacki J. 1885. Die Fische der Drau und ihres Gebietes. Wissenschaftliche Abhandlungen Jahresbericht des Steiermärkischen landschaft Untergymnasiums zu Pettau 16: 1-18.

Glowacki J. 1896. Die Fischfauna der Save und der Isonzo, StaatsUntergymnasium in Cilli, Celje, $37 \mathrm{p}$.

Gómez A, Lunt DH. 2006. Refugia within refugia: patterns of phylogeographic concordance in the Iberian Peninsula. In Weiss S, Ferrand N, eds. Phylogeography in southern European refugia: Evolutionary perspectives on the origins and conservation of European biodiversity, Kluwer Academic Press, Dordrecht, 155188.

Habdija I, Mrakovčić M, Primc Habdija B, Kerovec M, PlenkovićMoraj A. 2008. Sažeti prikaz fiziografskih, hidrogeoloških, ekoloških i biocenotičkih obilježja HR tipova tekućica definiranim prema deskriptorima sustava B ODV u hidrografskoj mreži Hrvatske, Prirodoslovno-matematički fakultet, Biološki odsjek, Zagreb, $155 \mathrm{p}$.

Heckel JJ, Knerr R. 1858. Die Süsswasserfische der Österreichischen Monarchie, mit Rücksicht auf die angränzenden Länder, Leipzig, 388 p.

Hirc D. 1896. Što priča naš narod o nekim životinjama. Zbornik za narodni život i običaje Južnih Slavena, 1: 1-26.

Jalžić B, Bedek J, Bilandžija H, Cvitanović H, Dražina T, Gottstein S, Gašpić FK, Lukić M, Ozimec R, Pavlek M, Slapnik R, Štamol V. 2010. Atlas špiljskih tipskih lokaliteta faune Republike Hrvatske, Croatian Biospeleological Society, and State Department for Nature Protection, Zagreb, 261 p. 
Jelić M, Klobučar GIV, Grandjean F, Puillandre N, Franjević D, Futo M, Amouret J, Maguire I. 2016. Insights into the molecular phylogeny and historical biogeography of the white-clawed crayfish (Decapoda, Astacidae). Mol Phylogenet Evol 103: 26-40.

Karamata S. 2006. The geological development of the Balkan Peninsula related to the approach, collision and compression of Gondwanan and Eurasian units. Geol Soc Spec Publ 260: 155178.

Klobučar GIV, Podnar M, Jelić M, Franjević D, Faller M, Štambuk A, Gottstein S, Simić V, Maguire I. 2013. Role of the Dinaric Karst (western Balkans) in shaping the phylogeographic structure of the threatened crayfish Austropotamobius torrentium. Freshw Biol 58: $1089-1105$

Knebelsberger T, Dunz AR, Neumann D, Geiger MF. 2014. Molecular diversity of Germany's freshwater fishes and lampreys assessed by DNA barcoding. Mol Ecol Resour 15: 562-572.

Kottelat M. 2007. Three new speceis of Phoxinus from Greece and southern France (Teleostei: Cyprinidae). Ichthyol Explor Freshw 18: $145-162$.

Kottelat M, Freyhof J. 2007. Handbook of European freshwater fishes, Maurice Kottelat (privately published) $646 \mathrm{p}$.

Langerhans RB, Gifford ME, Everton OJ. 2007. Ecological speciation in Gambusia fishes. Evolution 61: 2056-2074.

Langerhans RB, Reznick DN. 2010. Ecology and evolution of swimming performance in fishes: Predicting evolution with biomechanics. In Domenici P, Kapoor B, eds. Fish locomotion: An eco-ethological perspective, Boca Raton: CRC Press, pp. 200248.

Leigh JW, Bryant D. 2015. PopART: Full-feature software for haplotype network construction. Methods Ecol Evol 6: 1110-1116.

Leiner S. 1985. Ihtiofauna kopnenih voda Istre (Ichthyofauna of the mainland waters of Istria), Master thesis, Faculty of Science, Department of Biology, Zagreb.

Leiner S. 1998. Ribe hrvatskog slijevnog područja rijeke Neretve. Dubrovnik N.S., 9: 245-252.

Lelek A. 1987. Threatened fishes of Europe, European Committee for the Conservation of Nature and Natural Resources, Council of Europe, AULA - Verlag, Wiebelsheim, 343 p.

Lucek K, Kristjánsson BK, Skúlason S, Seehausen O. 2016. Ecosystem size matters: the dimensionality of intralacustrine diversification in Icelandic stickleback is predicted by lake size Ecol Evol 6: 5256-5272.

Machordom A, Doadrio I. 2001. Evidence of a Cenozoic BeticKabilian connection based on freshwater fish phylogeography (Luciobarbus, Cyprinidae). Mol Phylogenet Evol 18: 252-263.

Mamos T, Wattier R, Burzynski A, Grabowski M. 2016. The legacy of a vanished sea: A high level of diversification within a European freshwater amphipod species complex driven by $15 \mathrm{My}$ of Paratethys regression. Mol Ecol 25: 795-810.

Meštrov M, Stilinović B, Habdija I, Maloseja Z, Tavčar V, Kerovec M, Lattinger R, Prime B, Plenković A, Justić D, Futač N, Šoštarec V. 1989a. Biološko-ekološki odnosi podzemnih voda rijeke Save. Proceedings of the Workshop on "The Sava River, Preservation and water use”, JAZU, Zagreb, pp. 309-317.

Meštrov M, Tavčar V, Kerovec M. 1989b. Anthropogenic influence on the structure of macrozoobenthos in the streams of the mountain Psunj. Period Biol 91: 95.

Miller MA, Pfeiffer W, Schwartz T. 2010. Creating the Cipres Science Gateway for inference of large phylogenetic trees. In: Proceedings of the Gateway Computing Environments Workshop (GCE), 14 November 2010, New Orleans, LA, pp. 1-8.

Miočić-Stošić J, Jelić D, Bašić T, Kovačević M, Pjevac P, Žutinić P, Sučić I, Jelić M, Novosel L. 2012. Raznolikost ihtiofaune rijeke
Zrmanje južna Hrvatska (Diversity of ichthyofauna of the river Zrmanja southern Croatia). In Jelaska S, Klobučar G, Jelaska L, Leljak Levanić D, Lukša Ž, eds. Book of Abstracts 11th Croatian Biological Congress with International Participation, pp. 91-92.

Miró A, Ventura M. 2015. Evidence of exotic trout mediated minnow invasion in Pyrenean high mountain lakes. Biol Invasions 17: 791-803.

Mrakovčić M, Ćaleta M, Mustafić P, Marčić Z, Zanella D, Buj I. 2010. Izvješće za potrebe izrade prijedloga potencijalnih Natura 2000 područja - slatkovodne ribe, 2010, State Institute for Nature Protection, Zagreb.

Mrakovčić M, Kerovec M, Mišetić S, Schneider D, Tomašković N, Šurmanović D. 1996. Ichtiofauna of the Drava River Croatia. In: Berczik Á, ed. Limnologische Berichte Donau 1996, Wissenschaftliche Referate, MTA Ökol. Bot. Kutint. Magyar Dunakutató Állomás, pp. 345-348

Mrakovčić M, Mišetić S. 1988. Fish diversity and community structure in the river Krka, Dalmatia, Yugoslavia, Congress Abstract, Budapest, 145-145 p.

Mrakovčić M, Mustafić P, Brigić A, Buj I, Ćaleta M, Zanella D, Opačak A, Marčić Z, Mišetić S. 2007. Fish community alterations due to damming in the Neretva River. In: Buj I, Zanella L, Mrakovčić M, eds. Book of Abstracts XII European Congress of Ichthyology ECI XII, Croatian Ichthyological Society, Zagreb, pp. 235-235.

Mrakovčić M, Mustafić P, Mišetić S, Plenković-Moraj A, Mihaljević Z, Kerovec M, Zanella D, Ćaleta M, Marčić Z, Buj I, Kralj Borojević K, Gligora Udovič M, Žutinić P. 2014. Fizikalnokemijske, biološke i ihtiološke značajke nadzemnih voda hidroenergetskog sustava HE Varaždin, HE Čakovec i HE Dubrava u 2014. godini, Faculty of Science, Department of Biology, Zagreb.

Museth J, Hesthagen T, Sandlund OT, Thorstad EB, Ugedal O. 2007. The history of the minnow Phoxinus phoxinus (L.) in Norway: from harmless species to pest. J Fish Biol 71: 184-195.

Nylander JAA, Wilgenbusch JC, Warren DL, Swofford DL. 2008. AWTY (are we there yet?): a system forgraphi graphical exploration of MCMC convergence in Bayesian phylogenetics. Bioinformatics 24: 581-583.

Palandačić A, Bravničar J, Zupančić P, Šanda R, Snoj A. 2015. Molecular data suggest a multispecies complex of Phoxinus (Cyprinidae) in the Western Balkan Peninsula. Mol Phylogenet Evol 92: 118-123.

Palandačić A, Naseka A, Ramler D, Ahnelt A. 2017. Contrasting morphology with molecular data: an approach to revision of species complexes based on the example of European Phoxinus (Cyprinidae). BMC Evol Biol 17: 184. Doi: 10.1186/ s12862-017-1032-x.

Pažur K. 1969. Divovske pastrve u jezeru Lokvarka. Ribarstvo 24: 40-43.

Perdices A, Doadrio I, Economidis PS, Bohlen J, Banarescu P. 2003. Pleistocene effects on the European freshwater fish fauna: double origin of the cobitid genus Sabanejewia in the Danube basin (Osteichthyes: Cobitidae). Mol Phylogenet Evol 26: 289-299.

Perea S, Böhme M, Zupančič P, Freyhof J, Šanda R, Ozulug M, Abdoli A, Doadrio I. 2010. Phylogenetic relationships and biogeographical patterns in Circum-Mediterranean subfamily Leuciscinae (Teleostei, Cyprinidae) inferred from both mitochondrial and nuclear data. BMC Evol Biol 10: 265.

Plančić J. 1956. Tko je kriv za loše stanje na Vranskom jezeru. Morsko ribarstvo 8: 150.

Prelovšek M. 2010. Hydrology. In: Mihevc A, Prelovšek M,Zupan Hajna N, eds. Introduction to the Dinaric karst, Karst Research Institute at Research Centre of the Slovenian Academy of Sciences and Arts, Postojna, 25-29. 
Previšić A, Walton C, Kučinić M, Mitrikeski PT, Kerovec M. 2009. Pleistocene divergence of Dinaric Drusus endemics (Trichoptera, Limnephilidae) in multiple microrefugia within the Balkan Peninsula. Mol Ecol 18: 634-647.

Primc Habdija B, Plenković-Moraj A, Ternjej I, Špoljar M, Matoničkin Kepčija R, Gligora M, Kralj K, Sertić Perić M, Žutinić P. 2008. Plankton i fiziografska, hidrološka, ekološka i biološka obilježja HRL tipova jezera u hrvatskoj hidrografskoj mreži, Prirodoslovnomatematički fakultet, Biološki odsjek, Zagreb, 74 p.

Ramler D, Palandačić A, Delmastro GB, Wanzenböck J, Ahnelt H. 2017. Morphological divergence of lake and stream Phoxinus of Northern Italy and the Danube basin based on geometric morphometric analysis. Ecol Evol 7: 572-584.

Ronquist F, Teslenko M, van der Mark P, Ayres DL, Darling A, Höhna S, Larget B, Liu L, Suchard MA, Huelsenbeck JP. 2012. MrBayes 3.2: efficient Bayesian phylogenetic inference and model choice across a large model space. Syst Biol 61: 539-542.

Sabioncello I. 1967. Sistematika slatkovodnih riba. In: Livojević Z, Bojčić C, eds. Priručnik za slatkovodno ribarstvo, Posebna izdanja "Agronomskog glasnika", Zagreb, 21-90.

Sallai Z, Mrakovčić M. 2007. Protokol za istraživanje faune riba i praćenje stanja u rijeci Dravi. In: Purger JJ, ed. Priručnik za istraživanje bioraznolikosti duž rijeke Drave, University of Pecs, Pecs, 133-161.

Schmitt T. 2007. Molecular biogeography of Europe: pleistocene cycles and postglacial trends. Front Zool 4: 11.

Seeley HG. 1886. The Fresh-water fishes of Europe, Cassell and Company, London, Paris, New York, Melbourne, 444 p.

Simonović P, Povž M, Piria M, Treer T, Adrović A, Škrijelj R, Nikolić V, Simić V. 2015. Ichthyofauna of the River Sava System. In: Milačič R, Ščančar J, Paunović M, eds. The Sava River, Edition: The Handbook of Environmental Chemistry, vol. 31, Springer, Berlin, Heidelberg, pp. 361-400.

Simonović P, Tošić A, Škraba Jurlina D, Nikolić V, Piria M, Tomljanović T, Šprem N, Mrdak D, Milošević D, Bećiraj A, Dekić R, Povž M. 2017. Diversity of Brown trout Salmo cf. trutta (L.) in the River Danube basin of Western Balkans as assessed from the structure of their mitochondrial control region haplotypes. $J$ Ichthyol 57: 603-616.
Sofradžija A. 2009. Slatkovodne ribe Bosne i Hercegovine (Freshwater fishes of the Bosnia and Herzegovina), Vijeće Kongresa bošnjačkih intelektualaca, Sarajevo, 353 p.

Sofradžija A, Hadžiselimović R. 1981. Chromosomes of Yugoslav freshwater Cyclostomata and Pisces. Godišnjak Biološkog instituta Univerziteta u Sarajevu, 34: 117-152.

Stamatakis A. 2014. RAxML Version 8: A tool for phylogenetic analysis and post-analysis of large phylogenies. Bioinformatics 30 : 1312-1313.

Steindachner F. 1866. Über die Fische von Port Jackson in Australien. Anzeiger K Akad Wiss Math-Naturwiss Cl 3: 50-54.

Tamura K, Nei M. 1993. Estimation of the number of nucleotide substitutions in the control region of mitochondrial DNA in humans and chimpanzees. Mol Biol Evol 10: 512-526.

Tamura K, Stecher G, Peterson D, Filipski A, Kumar S. 2013. MEGA6: Molecular Evolutionary Genetics Analysis version 6.0. Mol Biol Evol 30: 2725-2729.

Trgovčić K. 2003. Characteristics of growth of the carp (Cyprinus carpio L.) in water reservoir Butoniga (Istra), Master thesis, Faculty of Science, Zagreb, $36 \mathrm{p}$.

Tvrtković N. 1985. Ribe Jugoslavije, HAZU, Zagreb, 27 p.

Valić D, Kapetanović D, Vardić Smrzlić I, Teskeredžić E. 2013. Parasitofauna of farmed fish. Impact on human health. In: Mitrov D, Pendovski L, Percinić FP, eds. Days of Veterinary Medicine, Faculty of Veterinary Medicine, Skopje, pp. 93-93.

Verovnik R, Sket B, Trontelj P. 2005. The colonization of Europe by the freshwater crustacean Asellus aquaticus (Crustacea: Isopoda) proceeded from ancient refugia and was directed by habitat connectivity. Mol Ecol 14: 4355-4369.

Vitecek S, Kučinić M, Previšić A, Živić I, Stojanović K, Keresztes L, Balint M, Hoppeler F, Waringer J, Graf W, Pauls SU. 2017. Integrative taxonomy by molecular species delimitation: multilocus data corroborate a new species of Balkan Drusinae microendemics. BMC Evol Biol 17: 129.

Vuković T, Ivanović B. 1971. Slatkovodne ribe Jugoslavije, Zemaljski muzej BiH-Prirodnjačko odjeljenje, 268 p.

Walker JA. 1997. Ecological morphology of lacustrine threespine stickleback Gasterosteus aculeatus L. (Gasterosteidae) body shape. Biol J Linn Soc 61: 3-50.

Cite this article as: Vucić M, Jelić D, Žutinić P, Grandjean F, Jelić M. 2018. Distribution of Eurasian minnows (Phoxinus: Cypriniformes) in the Western Balkans. Knowl. Manag. Aquat. Ecosyst., 419, 11. 